\title{
Recent shallowing of the thaw depth at Crater Lake, Deception Island, Antarctica (2006-2014)
}

\author{
M. Ramos ${ }^{\mathrm{a}, *}$, G. Vieira ${ }^{\mathrm{b}}$, M.A. de Pablo ${ }^{\mathrm{c}}$, A. Molina ${ }^{\mathrm{c}}$, A. Abramov ${ }^{\mathrm{d}}$, G. Goyanes $^{\mathrm{e}}$ \\ a Department of Physics and Mathematics, University of Alcalá, Madrid, Spain \\ b Centre for Geographical Studies - IGOT, Universidade de Lisboa, Lisbon, Portugal \\ c Department of Geology, Geography and Environment, University of Alcalá, Madrid, Spain \\ ${ }^{\mathrm{d}}$ Russian Academy of Sciences, Institute of Geography, Russia \\ e Instituto de Estudios Andinos “Don Pablo Groeber” (UBA-CONICET), Universidad de Buenos Aires, Argentina
}

\section{A R T I C L E I N F O}

\section{Article history:}

Received 19 January 2016

Received in revised form 11 July 2016

Accepted 12 July 2016

Available online 18 July 2016

\section{Keywords:}

Permafrost

Decreasing thaw depth

Active layer

Snow insulation

Antarctic peninsula

\begin{abstract}
A B S T R A C T
The Western Antarctic Peninsula region is one of the hot spots of climate change and one of the most ecologically sensitive regions of Antarctica, where permafrost is near its climatic limits. The research was conducted in Deception Island, an active stratovolcano in the South Shetlands archipelago off the northern tip of the Antarctic Peninsula. The climate is polar oceanic, with high precipitation and mean annual air temperatures (MAAT) close to $-3^{\circ} \mathrm{C}$. The soils are composed by ashes and pyroclasts with high porosity and high water content, with icerich permafrost at $-0.8^{\circ} \mathrm{C}$ at the depth of zero annual amplitude, with an active layer of about $30 \mathrm{~cm}$. Results from thaw depth, ground temperature and snow cover monitoring at the Crater Lake CALM-S site over the period 2006 to 2014 are analyzed. Thaw depth (TD) was measured by mechanical probing once per year in the end of January or early February in a $100 \times 100 \mathrm{~m}$ with a $10 \mathrm{~m}$ spacing grid. The results show a trend for decreasing thaw depth from ci. $36 \mathrm{~cm}$ in 2006 to $23 \mathrm{~cm}$ in 2014, while MAAT, as well as ground temperatures at the base of the active layer, remained stable. However, the duration of the snow cover at the CALM-S site, measured through the Snow Pack Factor (SF) showed an increase from 2006 to 2014, especially with longer lasting snow cover in the spring and early summer. The negative correlation between SF and the thaw depth supports the significance of the influence of the increasing snow cover in thaw depth, even with no trend in the MAAT. The lack of observed ground cooling in the base of the active layer is probably linked to the high ice/water content at the transient layer. The pyroclastic soils of Deception Island, with high porosity, are key to the shallow active layer depths, when compared to other sites in the Western Antarctic Peninsula (WAP). These findings support the lack of linearity between atmospheric warming and permafrost warming and induce an extra complexity to the understanding of the effects of climate change in the ice-free areas of the WAP, especially in scenarios with increased precipitation as snow fall.
\end{abstract}

(c) 2016 Elsevier B.V. All rights reserved.

\section{Introduction}

Deception Island is located in the South Shetlands archipelago, north of the Antarctic Peninsula (AP), one of Earth's regions with strongest atmospheric warming signal, with an increase of $c i .3^{\circ} \mathrm{C}$ in the MAAT from the 1950s (Marshall et al., 2002; Meredith and King, 2005; Turner et al., 2005; Turner et al., 2009; Turner et al., 2013). The environmental consequences of this warming on glaciers and ice-shelves have been widely studied, but the consequences for permafrost, are only now beginning to be investigated (Vieira et al., 2010; Bockheim et al., 2013). Permafrost temperature and active layer thickness (ALT) are Essential Climate Variables as defined by the Global Climate Observing System (GCOS/WMO)

\footnotetext{
* Corresponding author.

E-mail address: miguel.ramos@uah.es (M. Ramos).
}

(Smith and Brown, 2009., Bojinski et al., 2014) and are key indicators of climate change in the Polar Regions (Anisimov et al., 1997; Burgess et al., 2000), reflecting changes in the ground surface energy balance (World Meteorological Organization, 1997). The distribution and properties of permafrost and the ALT in the Antarctic Peninsula region are poorly understood (Bockheim, 1995; Bockheim et al., 2013). The situation started to change with the International Polar Year (IPY) 20072008, which was the framework for an international effort to improve monitoring of permafrost and the ALT across the Antarctic (Vieira et al., 2010).

The Circumpolar Active Layer Monitoring (CALM) program is a network of permafrost observatories distributed over both Polar Regions and selected mid-latitude mountain ranges (Brown et al., 2000). CALM is an international global-change monitoring program concerned with ALT dynamics and the shallow permafrost environment, with CALM 
sites in the Southern Hemisphere designated as CALM-S (Guglielmin, 2006; Nelson and Shiklomanov, 2010). CALM-S sites are also integrated in the Global Terrestrial Network for Permafrost (GTN-P, WMO/GCOS) (Burgess et al., 2000).

Low altitude permafrost temperatures are slightly below $0{ }^{\circ} \mathrm{C}$ in the South Shetlands, showing that the region is near its climatic boundary, thus being probably one of the regions with highest sensitivity to climate change in the Antarctic (Ramos et al., 2007; Ramos and Vieira, 2009; Bockheim et al., 2013). This fact reinforces the importance to study the evolution of permafrost and active layer in the region.

The CALM-S protocol as an approach to standardize ALT monitoring has been implemented by our team in Deception Island, one of the scarce areas of the South Shetlands allowing using mechanical probing to measure thaw depth. Despite being an active volcano, the high interstitial ice-content of permafrost and high porosity volcanoclastic soils, favour thermal insulation and permafrost is ubiquitous almost down to sea-level. Geothermal anomalies show only very local effects, mainly along faults and within buffers a few hundred meters wide (Goyanes et al., 2014). Therefore, the ALT conditions in most of the island are not affected by the geothermal heat flux.

CALM-S monitoring sites target at identifying the spatial variability of the ALT and the controlling effects of parameters such as topography, soil physics properties, vegetation, hydrology and snow cover. Observations are usually carried out in a $100 \times 100 \mathrm{~m}$ grid with sampling nodes at $10 \mathrm{~m}$ spacing, where TD is measured by mechanical probing close to the end of the thaw season. In complex topography sites, smaller grids may be implemented. Arrays of shallow boreholes for monitoring ground temperatures may also be used in areas where probing is not possible and a meteorological station is used to analyze the climate conditions. At some Antarctic sites, this approach is complemented with deeper boreholes that are monitored for permafrost temperatures (Vieira et al., 2010).
This paper aims at characterizing the active layer thermal regime and climate controls, through the analysis of thaw depth (TD), air and ground temperatures and snow cover observations at the Crater Lake CALM-S site in Deception Island using data from 2006 to 2014.

\section{Study area}

Deception Island $\left(62^{\circ} 55^{\prime} \mathrm{S}, 60^{\circ} 37^{\prime} \mathrm{W}\right)$ is located in the South Shetlands archipelago in the Bransfield Strait, about $100 \mathrm{~km}$ north of the Antarctic Peninsula (AP) (Fig. 1). The horseshoe shaped island is a stratovolcano with a diameter of $15 \mathrm{~km}$, a maximum elevation of $539 \mathrm{~m}$ asl at Mount Pond in the eastern part of the volcano rim and with a $7 \mathrm{~km}$ wide caldera open to the sea. About $57 \%$ of the island is covered by glaciers and an area of about $47 \mathrm{~km}^{2}$ is glacier free (Smellie and LópezMartínez., 2002).

The climate of the South Shetlands is cold-oceanic with frequent summer rainfalls and a moderate annual temperature range. MAAT are close to $-3{ }^{\circ} \mathrm{C}$ at sea level and average relative humidity is very high, ranging from 80 to $90 \%$. The weather conditions are dominated by the influence of the polar frontal systems, and atmospheric circulation is variable, with the possibility of winter rainfall (Styszynska., 2004). The annual meteorological data describe two seasons corresponding to the annual cycle of soil freezing and thawing (Ramos et al., 2012). Electrical resistivity surveying suggests permafrost thickness to be between 3 and $25 \mathrm{~m}$ in Deception Island (Vieira et al. 2008b; Bockheim et al., 2013; Goyanes et al., 2014).

As a result of recent eruptions, Deception Island is covered by volcanic ash and pyroclasts, and many of the glaciers remain ash-covered today. Pyroclastic deposits covered the snow mantle, and buried snow is still present at some sites. Deposits are very porous and insulating with high water/ice content near the surface, and give rise to a thin ALT, varying from 10 to $96 \mathrm{~cm}$ depth (Bockheim et al., 2013). On



Fig. 1. Location of Deception Island in the South Shetlands Archipelago (Antarctica). 
lower valley slopes, exposures of fossil snow (buried ice) with perennially frozen ice-cemented volcanic debris on top can be observed, testifying post-eruption aggradation of permafrost. At these sites, icecemented permafrost also occurs under the buried-ice layer. Buriedice is widespread on Deception Island, especially along the lower slopes, and ice-cemented permafrost occurs almost down to sea level as shown by geophysical surveying and trenches (Vieira et al., 2008b).

The Crater Lake CALM-S site is located in a small and relatively flat plateau-like step covered by volcanic and pyroclastic sediments at


was selected due to its flat characteristics, absent summer snow cover, distance to known geothermal anomalies, good exposure to the regional climate conditions (mitigating site specific effects and being representative in a regional context) and also because of its proximity to the Spanish station "Gabriel de Castilla". The ground surface is completely devoid of vegetation and the MAAT at the Crater Lake CALM-S site between 28/ $01 / 2009$ to $22 / 01 / 2014$ was $-3.0^{\circ} \mathrm{C}$.

Borehole temperature data show warm permafrost $\left(-0.3{ }^{\circ} \mathrm{C}\right.$ to $-0.9^{\circ} \mathrm{C}$ ), with thickness varying between 2.5 and $5.0 \mathrm{~m}$ (Vieira et al., 2008a; Ramos et al., 2010). The ALT derived from the borehole temperature profiles from 2010 to 2014 varied from 30 to $40 \mathrm{~cm}$.

\section{Materials and methods}

\subsection{Observational setting}

The Crater Lake CALM-S site consists of a $100 \times 100$ m grid with 121 nodes spaced at $10 \mathrm{~m}$ intervals and was installed in January 2006 (Figs. 2 and 3 ). Thaw depth (TD) is measured manually by mechanical probing (1-2 cm accuracy) once per year in late January or early February (coinciding with the end of summer), depending on logistical constraints since the research station is only open during the summer season (Ramos et al., 2007).



Fig. 3. General view of the Crater Lake CALM-S site, the arrows point the position of the camera (up right) and boreholes (center).

Since the installation of the CALM-S, the observational system has been continuously improved and the following parameters are currently monitored (Tables 1 and 2):

- Air temperatures at $1.60 \mathrm{~m}$ above the surface, monitored hourly since 2009.

- Ground temperatures in shallow boreholes down to $1.00 \mathrm{~m}$ (node 3, 3), $1.60 \mathrm{~m}$ (node 7,7) and $4.50 \mathrm{~m}$ (node 2,5) (Fig. 3). The boreholes have a diameter of $32 \mathrm{~mm}$, are cased with PVC pipes, air-filled and temperatures are measured with ibuttons (see Table 2 for specifications) at different depths starting at $2.5 \mathrm{~cm}$.

- Ground temperatures in 16 very shallow boreholes regularly distributed in the grid, with a single ibutton close to the base of the active layer (TBAL) at $40 \mathrm{~cm}$ depth (Table 2).

- Snow thickness estimated using near surface air temperature miniloggers installed in a stake $(5,10,20,40,80 \mathrm{~cm})$ and a Campbell CC640 time-lapse camera with daily pictures at 11:00, 12:00 and



Fig. 2. Instrumentation setting at the Crater Lake CALM-S site. 
Table 1

"Crater Lake" CALM-S site instrumentation position.

\begin{tabular}{|c|c|c|c|c|c|}
\hline $\begin{array}{l}\text { Coordinates } \\
\text { (node } 0,0 \text { ) }\end{array}$ & $\begin{array}{l}\text { Average } \\
\text { altitude } \\
\text { (m a.s.l.) }\end{array}$ & $\begin{array}{l}\text { Snow-stakes: } \\
\text { snow } \\
\text { temperature } \\
\text { array and } \\
\text { mini array }\end{array}$ & $\begin{array}{l}\text { Air } \\
\text { temperature }\end{array}$ & Boreholes & $\begin{array}{l}\text { Time lapse } \\
\text { camera }\end{array}$ \\
\hline $\begin{array}{l}62^{\circ} 59^{\prime} 06.7^{\prime \prime} \mathrm{S} \\
60^{\circ} 40^{\prime} 44.8^{\prime \prime} \mathrm{W}\end{array}$ & 85 & $\begin{array}{l}2 \text { nodes } \\
(3,3)(7,7)\end{array}$ & $\begin{array}{l}1 \\
\text { node } \\
(2,2)\end{array}$ & $\begin{array}{l}4.50 \mathrm{~m} \\
\text { node }(2,5) \\
1.00 \mathrm{~m} \\
\text { node }(3,3) \\
1.60 \mathrm{~m} \\
\text { node }(7,7)\end{array}$ & 1 \\
\hline
\end{tabular}

13:00 (local solar time). This approach allows evaluating the snow distribution.

\subsection{Estimation of snow thickness}

In order to estimate snow thickness, near-surface temperatures acquired by an array of sensors installed along a $1.60 \mathrm{~m}$ long stake, were analyzed. The method implemented by Lewkowicz and Bonnaventure (2008) and based on the changes in thermal regime along the stake when sensors are inside the snow pack, was used.

The daily snow thickness $\left(\mathrm{x}_{\mathrm{i}}\right)$ was classified according to the following levels: $\mathrm{x}_{1} \leq 10 \mathrm{~cm}, 10 \mathrm{~cm}<\mathrm{x}_{2} \leq 20 \mathrm{~cm}, 20 \mathrm{~cm}<\mathrm{x}_{3} \leq 40 \mathrm{~cm}$, considering that the periods of snowpack persistence for each level are $\left(t_{1}, t_{2}\right.$ and $t_{3}$ ). The Mean Snow Layer Thickness (MSLT) for the entire snow cover period $\left(t=t_{1}+t_{2}+t_{3}\right)$ for each of the snow stakes was calculated using the following Eq. (1).

$\operatorname{MSLT}($ node $)=\frac{\left[t_{1} \times 0.1+t_{2} \times 0.2+t_{3} \times 0.4\right]}{\sum_{i} t_{i}}(m)$.

The mean snow pack factor (SF) aims at assessing an annual average of snow distribution over the CALM-S grid and is an average of the MSLT at both snow stakes (Eq. (1)).

$S F=\frac{\operatorname{MSLT}(3 ; 3)+\operatorname{MSLT}(7 ; 7)}{2}(m)$

\section{Results}

\subsection{Active layer}

Fig. 4a shows the evolution of thaw depth (TD) at the Crater Lake CALM-S grid from 2006 to 2014. The mean TD for the 121 nodes for the whole period was $29.7 \mathrm{~cm}$, but the nine year time series shows a decreasing average TD from $35.5 \mathrm{~cm}$ in 2006 to $23.1 \mathrm{~cm}$ in 2014. Although not constant, with minor increases in TD in 2009 and 2012, the trend is noticeable and followed with higher irregularity by the local maxima and minima measured in individual nodes. Fig. 5 shows the spatial distribution of TD as measured in the grid nodes along the study period. The increasing trend observed in the average values is also clear in the spatial patterns of thaw.

Fig. $4 \mathrm{~b}$ shows the evolution of the air temperatures at the study site from 2009 to 2014. Mean annual air temperature was very stable around $-3^{\circ} \mathrm{C}$, the same happening with absolute maxima and minima. The extreme records were $+7.8^{\circ} \mathrm{C}$ in 2010 and $-24.0^{\circ} \mathrm{C}$ in 2009 .

The mean ground temperature close to the base of active layer (TBAL) in the 16 very shallow boreholes from 2008 to 2013 was $-1.3^{\circ} \mathrm{C}$, with minor interannual changes and no appreciable trend. The mean maxima were slightly above $0{ }^{\circ} \mathrm{C}$, showing an annual extreme value of $0.5^{\circ} \mathrm{C}$ (2008 and 2009) and the minima were always below $-4{ }^{\circ} \mathrm{C}$, down to $-9.3^{\circ} \mathrm{C}$ in 2011 . Accounting for the instrumental errors of the monitoring devices, the maxima was therefore always close to the water melting point in normal conditions.

\subsection{Permafrost}

The borehole temperatures from 2010 to 2013 show that the maximum active layer thickness (ALT) calculated using the $0{ }^{\circ} \mathrm{C}$ isotherm was $0.40 \mathrm{~m}$ with an isothermal transition in the range of 0.4 to $1.2 \mathrm{~m}$, and the mean annual ground surface temperature, at $2,5 \mathrm{~cm}$ depth was $-1.7^{\circ} \mathrm{C}$, showing an annual extreme value of $10.7^{\circ} \mathrm{C}(2013)$ and the minima were always below $-8.1{ }^{\circ} \mathrm{C}$, down to $-16.0^{\circ} \mathrm{C}$ in 2012 . The depth of zero annual amplitude should be slightly below the bottom of the borehole, just below $4.50 \mathrm{~m}$, with a temperature of ci. $-0.9{ }^{\circ} \mathrm{C}$. Fig. 6 shows the thermal envelope for 2010 to 2013 (2012 is not represented due to the data series is not competed).

\subsection{Average snow pack}

The dataset measured by the snow stake installed in the nodes $(3,3)$ and $(7,7)$, complemented with the pictures taken by the digital camera, allowed characterizing the evolution of the snow pack from 2008 to 2013 (Fig. 7).

If we account for the number of days of snow pack duration $\left(t_{i}\right)$ below the identified threshold thicknesses $\left(x_{1} \leq 10 \mathrm{~cm}\right.$, $10 \mathrm{~cm}<\mathrm{x}_{2} \leq 20 \mathrm{~cm}, 20 \mathrm{~cm}<\mathrm{x}_{3} \leq 40 \mathrm{~cm}$ ), the maximum value of $\mathrm{t}_{1}$ occurred in 2010 (137 days) at node (3,3) and the minimum occurred in

Table 2

Crater Lake CALM-S site instrumentation details.

\begin{tabular}{|c|c|c|c|c|c|c|}
\hline & Node & Sensor type & $\begin{array}{l}\text { Accuracy }\left(^{\circ}\right. \\
\text { C) }\end{array}$ & $\begin{array}{l}\text { Resolution }\left(^{\circ}\right. \\
\text { C) }\end{array}$ & $\begin{array}{l}\text { Sampling rate } \\
\text { (h) }\end{array}$ & $\begin{array}{l}\text { Sensor position } \\
(\mathrm{cm})\end{array}$ \\
\hline Air temperature & $(2,2)$ & $\begin{array}{l}\text { Pt-100, } \\
\text { Tinytag }\end{array}$ & 0.2 & 0.05 & 1 & 160 (height) \\
\hline Borehole $(4.50 \mathrm{~m})$ & $(2,2)$ & $\begin{array}{l}\text { Ibutton } \\
\text { DS1922L }\end{array}$ & 0.5 & 0.06 & 3 & $\begin{array}{l}5,10,20,40,80,120,160,200,250,300,350,400,450 \\
\text { (depth) }\end{array}$ \\
\hline $\begin{array}{l}\text { Borehole } \\
(1 \mathrm{~m})\end{array}$ & $(3,3)$ & $\begin{array}{l}\text { Ibutton } \\
\text { DS1922L }\end{array}$ & 0.5 & 0.06 & 3 & $\begin{array}{l}2.5,5,10,20,40,70,100 \\
\text { (depth) }\end{array}$ \\
\hline $\begin{array}{l}\text { Borehole } \\
(1.6 \mathrm{~m})\end{array}$ & $(7,7)$ & $\begin{array}{l}\text { Ibutton } \\
\text { DS1922L }\end{array}$ & 0.5 & 0.06 & 3 & $\begin{array}{l}2.5,5,10,20,40,70,100,150 \\
\text { (depth) }\end{array}$ \\
\hline $\begin{array}{l}\text { Temperature close to the base of the } \\
\text { active layer }\end{array}$ & $\begin{array}{l}20 \mathrm{~m} \\
\text { interval } \\
\text { ( } 16 \text { nodes) }\end{array}$ & $\begin{array}{l}\text { Ibutton } \\
\text { DS1921G }\end{array}$ & 1 & 0.5 & 3 or 4 & $\begin{array}{l}40 \\
\text { (depth) }\end{array}$ \\
\hline Snow stakes & $(3,3)(7,7)$ & $\begin{array}{l}\text { Ibutton } \\
\text { DS1921G }\end{array}$ & 1 & 0.5 & 3 & $\begin{array}{l}5,10,20,40,80 \\
\text { (height) }\end{array}$ \\
\hline
\end{tabular}







2008 (66 days) at node (7,7) (Figs. 8a, b). The number of days with $<20 \mathrm{~cm}$ of snow cover $\left(t_{2}\right)$ showed a maximum of 175 days in 2013 in node $(3,3)$, while the threshold $40 \mathrm{~cm}$ was only attained at node $(7,7)$.

Node $(7,7)$ showed an earlier snow pack setting and later melt, resulting in longer lasting snow pack every year. The snow thickness frequently reached over $40 \mathrm{~cm}$ at node $(7,7)$, but never in $(3,3)$. In the later, snow was generally $10-20 \mathrm{~cm}$ thick, but rarely passed $20 \mathrm{~cm}$. In node $(7,7)$, the snow thickness showed very frequently 20 to $40 \mathrm{~cm}$. The snow pack generally settled around mid-April to May and lasted until mid-November to December eve first January, with a significant delay in the melt date in the more recent years.

The results from Eqs. (1) and (2) are shown in Fig. 8c. The larger values of SF occurred in $2013(29 \mathrm{~cm})$ and $2008(23 \mathrm{~cm})$, and the lower in $2011(17 \mathrm{~cm})$ and $2009(18 \mathrm{~cm})$.

\section{Discussion}

\subsection{Thaw depth}

The analysis of the spatial distribution of thaw depth across the Crater Lake CALM-S site (Fig. 5) shows that the area with small values corresponds to sectors which are less wind-exposed and with lower relief, showing also a longer and more stable snow cover. This is also shown in the longer lasting and thicker snow pack in node $(7,7)$ than in $(3,3)$ (Figs. 7 and 8 ).

Despite a slight interannual variability, the decreasing trend in thaw depth between $2006(35.5 \pm 2 \mathrm{~cm})$ and $2014(23.1 \pm 2 \mathrm{~cm})$ shows a statistically significant coefficient of correlation of 0.85 (Fig. 9). This trend is consistent with the deceleration in the glacial retreat identified in Livingston Island by Navarro et al. (2013) and may be also related to an increase of snow precipitation pointed by Osmanoglu et al. (2014). The impacts of increased snow thickness on a decreasing active layer depth have also been shown by Jiménez et al. (2014). They studied the thermal behaviour of the active layer by mean of the enthalpy model in function of the snow cover near to the Hurd Peninsula (Livingston Island). Their results showed a reduction of the soil surface energy balance when increasing the snow layer thickness. In Byers Peninsula (Livingston Island), De Pablo et al. (2016) studied the evolution of the snow cover at the Limnopolar Lake CALM-S site during the 2009-2014 period. Their reported about similar snow depths of about $45 \mathrm{~cm}$, as well as similar snow onset about constant with small variations of 10 days in early March. However, the snow offset had significant 



Fig. 5. Summer thaw depth from 2006 to 2014 at the Crater Lake CALM-S site. Scale in decameters.

variations, increasing in the last three years for $>60$ days. Therefore, their main conclusion is that the increase in the snow duration is resulting in the reduction of the thaw period in the ground. In Byers Peninsula as well, but in three different monitoring sites with specific geomorphological characteristics, Oliva et al. (2016) extrapolated the presence of stable frozen layer conditions in the range of 85 to $155 \mathrm{~cm}$. These depths agree with the $1.3 \mathrm{~m}$ reported for the depth of the permafrost table at the nearby Limnopolar Lake CALM-S site by de Pablo et al. (2014).

In other localities of the Antarctic Peninsula region, the ALT showed also a high variability, such as on Signy Island, where ALT ranged between 0.8 and $1.8 \mathrm{~m}$ influenced by vegetation (Guglielmin et al., 2012), or on James Ross Island where the ALT reached 0.5 to $0.8 \mathrm{~m}$ at sites with different lithological properties under colder climate conditions (Hrbáček et al., 2016).

In our study site in Deception Island the influence of the snow pack on the mean annual thaw depth is well represented by SF through a negative correlation, showing that the increase of snow layer thickness and it persistence period causes a decrease or the maximum thaw depth, as shown in Fig. 10.

\subsection{Temperature close to the base of the active layer}

The mean temperature close to the base of the active layer (TBAL) was stable during the whole study period (Fig. 4c). During winter and spring, the snow cover influences significantly TBAL. Fig. 11 shows 





represented (2010, 2011 and 2013, 2012 is not represented because is not complete the data series).

that the years with less days of snow cover (2010,2011,2012 and 2014) present a good linear fit between the minimum annual air temperature and TBAL, implying a poor thermal insulation of the snow pack. On the other hand, the two years with longer snow pack duration (2009 and 2013), plot clearly outside the best fit.

It is also worth comparing 2009 and 2011. The former showed an air temperature minimum of $-24.0^{\circ} \mathrm{C}$ and a minimum TBAL of $-6.0^{\circ} \mathrm{C}$, while the later, showed higher minima $\left(-19.4^{\circ} \mathrm{C}\right)$, but a lower minimum TBAL $\left(-9.3^{\circ} \mathrm{C}\right)$. In this case, SF was very similar in both years (18 and $17 \mathrm{~cm}$ ), but snow cover settled one month earlier and more


Fig. 7. Snow pack thickness at the Crater Lake CALM-S site from 2008 to 2013. a) node $(3,3)$, b) node $(7,7)$ homogeneously in 2009 (15/04/2009) than in 2011 (18/05/2011), which generated a stronger thermal insulation in the former. This effect seems to have contributed to the largest TD in the summer of 2010 $(31.5 \mathrm{~cm})$, when compared to the summer of $2012(28.7 \mathrm{~cm})$.

The annual maxima of TBAL were stable, within $0.0 \pm 0.5^{\circ} \mathrm{C}$ due to the damping effect caused by latent heat fluxes on top of the ice-rich permafrost during the thaw season.

\subsection{Permafrost temperatures}

Maximum annual ground temperatures show similar values and active layer depth of approximately $0.4 \mathrm{~m}$ at Crater Lake CALM-S in the 4 years with data. Fig. 6 shows a typical permafrost temperature profile into the borehole STS- 1 node $(2,5)$ at Crater Lake, with maximum summer temperatures nearly isothermal at about $0{ }^{\circ} \mathrm{C}$ from 0.4 to $1.2 \mathrm{~m}$ depth. This temperature profile reflects the influence of the ice rich permafrost, as well as of the saturated layer just above the permafrost table, which mitigate ground warming. The small interannual range in the maximum mean temperatures for the shallower sensor $(2.5 \mathrm{~cm}$ depth) at the different years, varying from $8.1^{\circ} \mathrm{C}$ in 2010 to $10.7^{\circ} \mathrm{C}$ in 2013 is due to the absence of snow during the summer, small interannual air temperature range with similar maxima and latent heat effects due to the high moisture content of the ground.

However, the ground temperature minima in this shallow depth $(2.5 \mathrm{~cm})$ are very variable inter-annually, with values from $-8.1{ }^{\circ} \mathrm{C}$ in 2013 to $-16.0{ }^{\circ} \mathrm{C}$ in 2012 , reflecting a strong influence from snow cover variability and differences in winter air temperatures.

The mean annual ground temperatures vary very slightly with depth (ci. $1.1^{\circ} \mathrm{C}$ ). MGST is $-1.7 \pm 0.5^{\circ} \mathrm{C}$ which corresponds to a thermal offset of about $0.8{ }^{\circ} \mathrm{C}$.

\subsection{Average snow pack}

Snow pack thickness data shows that snow settles between 2 and 4 weeks earlier at node $(7,7)$ than $(3,3)$, which is at a more convex site and closest to the interfluve (Figs. 5 and 8). A similar effect occurs at snow melt, with the ground becoming snow free about a week later at node (7,7). This results in an average of more 27 days per year of 




$$
\text { B. NODE }(7,7)
$$



C




pack thickness and Snow Pack Factor (SF).

snow cover difference between the nodes $(3,3)$ and (7,7). MSLT values are also higher at $(7,7)(25 \mathrm{~cm}$ vs $15 \mathrm{~cm})$, reflecting the wind sheltered position of that part of the CALM-S site (Fig. 8c). These spatial differences also affect the spatial distribution of TD (Fig. 5).

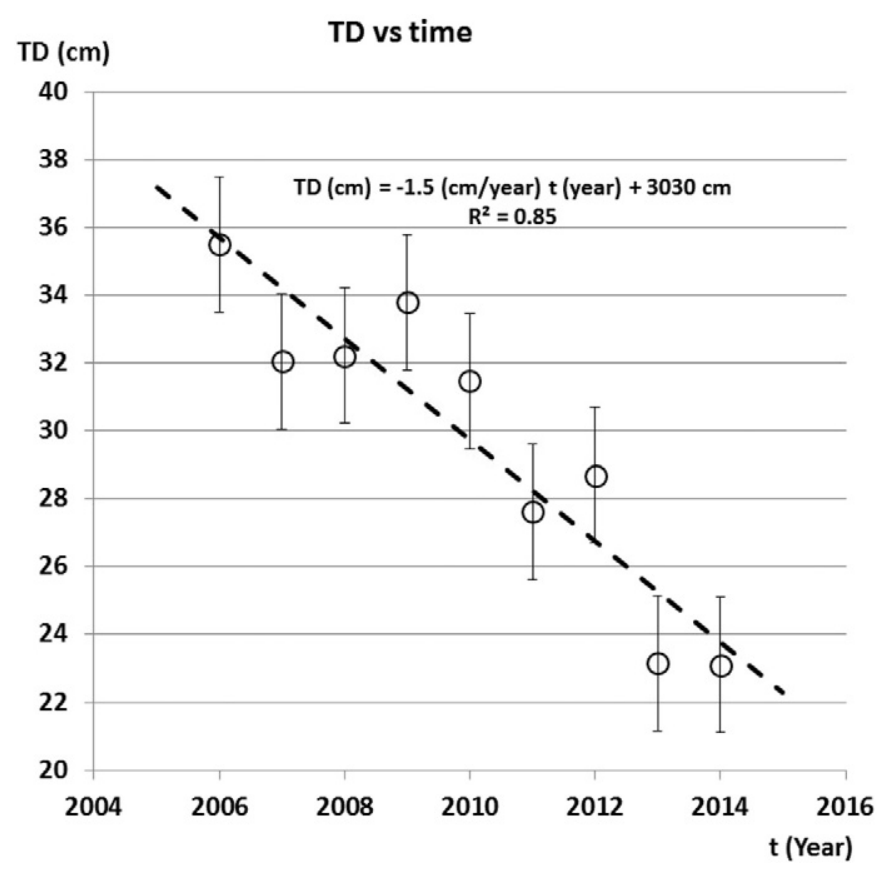

Fig. 9. Summer mean thaw depth in Crater Lake CALM-S from 2006 to 2014.

\section{Conclusions}

Ground temperature observations from the Crater Lake CALM-S site show that permafrost is warm, with temperatures close to $-0.9{ }^{\circ} \mathrm{C}$, with an active layer depth of ci. $40 \mathrm{~cm}$ and a thermal offset of $0.8^{\circ} \mathrm{C}$. The zero annual temperature depth is shallow and should be just below $4.5 \mathrm{~m}$ depth in contrast to other sites in the Western Antarctic Peninsula in high diffusivity bedrock settings (Ramos and Vieira, 2009; Bockheim et al., 2013; Guglielmin, et al., 2014). These characteristics are strongly influenced by the high porosity pyroclastic debris of Deception Island, which show a high ice-content at the base of the active layer.

Contrary to what would be expected given the general warming signal of the Western Antarctic Peninsula during the last decades, the thaw depth measured during the summer at the Crater Lake CALM-S site showed an approximately linear decreasing trend from 2006 to 2014 at a rate of about $1.5 \mathrm{~cm} /$ year. The mean annual air temperatures from 2008 to 2014 were relatively stable at $\mathrm{ci}-3{ }^{\circ} \mathrm{C}$, therefore showing no clear control on the active layer thinning. The temperatures at $40 \mathrm{~cm}$ depth also showed no trend during the same period, which means that the thinning was not due to increase MAAT and also did not resulted in a cooling at shallow depth. The main factor controlling the decreasing thaw depth was snow cover, with increased duration, especially during the spring and early summer, thus insulating the ground from warming. The reason for this phenomena not having been accompanied by ground cooling is probably related to the high moisture content and ice-rich permafrost in the transient layer, which mitigate temperature change.

The results presented in this paper are limited to a small number of years but this is one of the longest data series on thaw depth from an Antarctic CALM-S. The results should be interpreted with caution, but they support the fact that permafrost and active layer dynamics in the Maritime Antarctic is complex and cannot be directly linked to 




Fig. 10. Maximum thaw depth (TD) as function of the Snow factor (SF) for the Crater Lake CALM-S site between 2008 and 2013.

atmospheric warming alone. The changing snow cover plays a major role in the ground thermal regime and on permafrost and it needs to be better assessed, especially since regional models indicate an increase in precipitation following atmospheric warming and winter sea ice losses in the Western Antarctic Peninsula.

\section{Acknowledgements}

Authors thank to the Spanish Polar Program, Unit of Marine Technology from Spanish National Research Council, as well as to the Spanish Army and Spanish Navy crews involved on Antarctic Campaigns for made possible the continuous data acquisition. Our special thanks to "Gabriel de Castilla" Spanish Antarctic Station. This research was possible thanks to financial support of PERMATHERMAL (CONV-2015/001), PERMASNOW (CTM2014-50521-R), ANTARPERMA (CTM2011-15565E), and PERMAPLANET (CTM2009-10165) research projects from the Spanish National Research Program.



Fig. 11. Minimum temperature close to the base of the active layer (TBAL) versus minimum air temperature from 2009 to 2014.

\section{References}

Anisimov, O.A., Shiklomanov, N.I., Nelson, F.E., 1997. Global warming and active layer thickness: results from transient general circulation models. Glob. Planet. Chang. 15, 61-77 (ISSN: 0921-8181).

Bockheim, J.G., 1995. Permafrost distribution in the Southern Circumpolar Region and its relation to the environment: a review and recommendations for further research. Permafr. Periglac. Process. 6, 27-45.

Bockheim, J., Vieira, G., Ramos, M., López-Martínez, J., Serrano, E., Guglielmin, M., Wilhelm, K., Nieuwendam, A., 2013. Climate warming and permafrost dynamics in the Antarctic Peninsula region. Glob. Planet. Chang. 100, 215-223. http://dx.doi.org/ 10.1016/j.gloplacha.2012.10.018 (ISSN: 0921-8181).

Bojinski, S., Verstraete, M., Peterson, T.C., Richter, C., Simmons, A., Zemp, M., 2014. The concept of essential climate variables in support of climate research applications, and policy. Am. Meteorol. Soc. (September 2014), 1431-1443.

Burgess, M.M., Smith, S.L., Brown, J., Romanovsky, V., Hinkel, K., 2000. Global Terrestrial Network for Permafrost (GTNet-P) permafrost monitoring contributing to global climate observations. Geol. Surv. Can. 1-7 (Current Research 2000E14).

Brown, J., Hinkel, K.M., Nelson, F.E., 2000. The circumpolar active layer monitoring (CALM) program: research designs and initial results. Polar Geogr. 24 (3), 165-258.

De Pablo, M.A., Ramos, M., Molina, A., 2014. Thermal characterization of the active layer at the Limnopolar Lake CALM-S site on Byers Peninsula (Livingston Island), Antarctica. Solid Earth 5, 721-739.

De Pablo, M.A., Ramos, M., Molina, A., 2016. Snow cover evolution, on 2009-2014, at the Limnopolar Lake CALM-S site on Byers Peninsula, Livingston Island, Antarctica. Catena $149,538-547$.

Goyanes, G.A., Vieira, G. Caselli, A., Mora, C. Ramos, M. De Pablo, M.A., Neves, M., Santos, F., Bernardo, I., Gilichinsky, D., Abramov, A., Batista, V., Melo, R., Niewendam, A., Ferreira, A., Oliva, M., 2014. Regimen termico y variabilidad espacial de la capa activa en isla decepcion, Antartida. Revista de la Asociación Geológica Argentina. vol. 71 (No 1), 112-124 (ISSN 1851-8249 (en línea). ISSN 1669-7316 (impreso). http:// ppct.caicyt.gov.ar/index.php/raga/issue/view/192/showToc).

Guglielmin, M., 2006. Ground surface temperature (GST), active layer, and permafrost monitoring in continental Antarctica. Permafr. Periglac. Process. 17 (2), 133-143. http://dx.doi.org/10.1002/ppp.553.

Guglielmin, M., Worland, M.R., Cannone, N., 2012. Spatial and temporal variability of ground surface temperature and active layer thickness at the margin of Maritime Antarctica Signy Island. Geomorphology 155, 20-33.

Guglielmin, M., Worland, M.R., Baio, F., Convey, P., 2014. Permafrost and snow monitoring at Rothera Point (Adelaide Island, Maritime Antarctica): implications for rock weathering in cryotic conditions. Geomorphology 225, 47-56. http://dx.doi.org/10. 1016/j.geomorph.2014.03.051.

Hrbáček, F., Oliva, M., Laska, K., Ruiz-Fernández, J., de Pablo, M.A., Vieira, G., Ramos, M., Nývlt, D., 2016. Active layer thermal regime in two climatically contrasted sites of the Antarctic Peninsula region. Cuadernos de Investigación Geográfica (In press).

Jiménez, JJ, Ramos, M, De Pablo, M.A., Molina, A, 2014.Variabilidad térmica de la capa activa, acoplada al espesor nival, en las proximidades de la BAE Juan Carlos I. Avances métodos y técnicas de estudio en el periglaciarismo. Gómez, A; Salvador, F; Oliva, M; 
Salvá, M (eds.). Publicacions i edicions de la Universitat de Barcelona. Barcelona (2014). pp. 287-300. (ISBN-978-84-475-3830-0).

Lewkowicz, A.G., Bonnaventure, P.P., 2008. Interchangeability of mountain permafrost probability models, Northwest Canada. Permafr. Periglac. Process. 19, 49-62. http:// dx.doi.org/10.1002/ppp.612

Marshall, G.J., Lagun, V., Lachlan-Cope, T.A., 2002. Changes in Antarctic Peninsula tropospheric temperatures from 1956 to 1999: a synthesis of observations and reanalysis data. Int. J. Climatol. 22, 291-310.

Meredith, M.P., King, J.C., 2005. Rapid climate change in the ocean west of the Antarctic Peninsula during the second half of the 20th century. Geophys. Res. Lett. 32, L19604.

Nelson, F.E., Shiklomanov, N.I., 2010. The circumpolar active layer monitoring network-CALM III (2009-2014): long-term observations on the climate-active layer-permafrost system. In: Blanco, J.J., Ramos, M., de Pablo, M.A. (Eds.), Proceedings of II Iberian Conference of the International Permafrost Association Periglacial, Environments, Permafrost and Climate Variability. UAH, pp. 9-15 (ISBN: 978-84-9138885-5).

Navarro, F.J., Jonsell, U.Y., Corcuera, M.I., Martín-Español, 2013. Decelerated mass loss of Hurd and Johnsons Glaciers. Livingston Island, Antarctic Peninsula. J. Glaciol. 59 (No. 213). http://dx.doi.org/10.3189/2013JoG12J144.

Osmanoglu, B., Navarro, F.J., Hock, R., Braun, M and M.I. Corcuera, 2014. Surface velocity and mass balance of Livingston Island ice cap. Antarctica. Cryosphere, 8, 18071823, dói:http://dx.doi.org/10.5194/tc-8-1807-2014.

Oliva, M., Hrbacek, F., Ruiz-Fernández, J., de Pablo, M.A., Ramos, M., Vieira, G., Antoniades, D., 2016. Active Layer Dynamics in Three Topographically Distinct Lake Catchments in Byers Peninsula (Livingston Island, Antarctica). Catena (Accepted).

Ramos, M., Vieira, G., Gruber, S., Blanco, J.J., Hauck, C., Hidalgo, M.A., Tome, D., Neves, M., Trindade, A., 2007. Permafrost and active layer monitoring in the Maritime Antarctic: preliminary results from CALM sites on Livingston and Deception Islands. U.S. Geological Survey and The National Academies; USGS OF-2007-1047, Short Research Paper 070 http://dx.doi.org/10.3133/of2007-1047srp070.

Ramos, M., Vieira, G., 2009. Evaluation of the ground surface enthalpy balance from bedrock shallow borehole temperatures (Livingston Island, Maritime Antarctic). Cryosphere 3, 133-145 (www.the-cryosphere.net/3/133/2009/).

Ramos, M., Vieira, G., Guilichinski, D., de Pablo, M.A., Ramos, M., de Pablo, M.A., 2010. Nuevas estaciones de medida del régimen térmico del permafrost en el área de "Crater Lake”. Isla Decepción (Antártida). Resultados preliminares”. In: Blanco, J.J. (Ed.), Proceedings of II Iberian Conference of the International Permafrost Association Periglacial, environments, permafrost and climate variability. UAH, pp. 93-109 (ISBN: 978-84-9138-885-5).

Ramos, M., De Pablo, M.A., Sebastian, E., Armiens, C., Gómez-Elvira, J., 2012. Temperature gradient distribution in permafrost active layer, using a prototype of the ground temperature sensor (REMS-MSL) on deception island (Antarctica). Cold Reg. Sci. Technol. 72, 23-32. http://dx.doi.org/10.1016/j.coldregions.2011.10.012 (ISSN: 0165-232X).

Smith, S., Brown, J., 2009. Assessment of the Status of the Development of the Standards for the Terrestrial Essential Climate Variables - T7 - Permafrost and Seasonally Frozen Ground.

Styszynska, A., 2004. The origin of coreless winters in the South Shetlands area (Antarctica). Pol. Polar Res. 25, 45-66.

Smellie, J.L., López-Martínez, J., 2002. Introduction to the geology and geomorphology of Deception Island. In: López-Martínez, J., Smellie, J.L., Thomson, J.W., Thomson, M.R.A. (Eds.), BAS Geomap Series. British Antarctic Survey, Cambridge, pp. 1-6.

Turner, J., Colwell, S.R., Marshall, G.J., Lachlan-Cope, T.A., Carleton, A.M., Jones, P.D., Lagun, V., Reid, P.A., Iagovkina, S., 2005. Antarctic climate change during the last 50 years. Int. J. Climatol. 25, 279-294.

Turner, J., Bindschadler, R., Convey, P., et al., 2009. Antarctic Climate Change and the Environment. Scientific Committee on Antarctic Research. England, Cambridge.

Turner, J., Barrand, N.E., Bracegirdle, T.J., Convey, P., Hodgson, D.A., Jarvis, M., Jenkins, A. Marsall, G., Meredth, M.P., Roscoe, H., Shanklin, J., 2013. Antarctic Climate Change and the Environment: An Update. Polar record. 1-23. http://dx.doi.org/10.1017/ S0032247413000296 ((About DOI), Published online: 18 April 2013).

Vieira, G., Lopez-Martinez, J., Serrano, E., Ramos, M., Gruber, S., Hauck, C., Blanco, J.J. 2008a. Geomorphological observations of permafrost and ground-ice degradation on Deception and Livingston Islands, Maritime Antarctica. In: Kane, D., Hinkel, K. (Eds.), Proceedings of the 9th International Conference on Permafrost, 29 June-3 July 2008, Fairbanks, Alaska, Extended Abstracts vol. 1. University of Alaska Press, Fairbanks, pp. 1839-1844 (ISBN 978-0-980017 9-2-2).

Vieira, G., Hauck, C., Gruber, S., Blanco, J.J., Ramos, M., 2008b. Massive Ice Detection Using Electrical Tomography Resistivity. Examples From Livingston and Deception Islands, Maritime Antarctic. Proceedings of the VI Assembleia Ibérica de Geofísica, Tomar.

Vieira, G., Bockheim, J., Guglielmin, M., Balks, M., Abramov, A., Boelhouwers, J., Cannone, N., Ganzert, L., Gilichinsky, D.A., Gotyachkin, S., Lopez-Martinez, J., Meiklejohn, I., Raffi, R., Ramos, M., Schaefer, C., Serrano, E., Simas, F., Sletten, R., Wagner, D., 2010. Thermal state of permafrost and active-layer monitoring in the Antarctic: advances during the International Polar Year 2007-2009. Permafr. Periglac. Process. 21 (2), 182-197. http://dx.doi.org/10.1002/ppp.685 (ISSN: 1045-6740).

World Meteorological Organization, 1997. Global Climate Observing System GCOS/GTOS. Plan for Terrestrial Climate Related Observations. Version 2.0, GCOS-32, WMO/TD, No 796. UNEP/DEIA/TR97-7. WMO, Geneva, Switzerland (130 pages). 